\title{
Russia's Policy on Providing Security in Central Asia at the Beginning of the XXI Century
}

\author{
Albert Beloglazov \\ Kazan (Volga Region) Federal University, Russian Federation \\ Institute of International Relations, History and Oriental Studies \\ Email: Albert.Beloglazov@kpfu.ru
}

Doi:10.5901/mjss.2015.v6n3s2p219

\section{Abstract}

The importance of the problem under study is suggested by the increasing threats and challenges to the security of Central Asia at the beginning of XXI century as well as the necessity to counteract them. The objectives of the article are to make a research of Russia's policies on providing regional security in Central Asia from 2000 to 2014. To achieve these objectives the activity of Russia in the region is subdivided into 4 stages, all of which are briefly described. The particular emphasis is given to the role of such international organizations as Shanghai Cooperation Organization and Collective Security Treaty Organization. The materials of the article might be useful in conducting scientific research on the issues of Central Asia, providing lectures and seminars in training, also planning specific measures to counteract the treats of regional security.

Keywords: Central Asia, security, Russian Federation, Afghanistan, Kazakhstan, Kirgizia, Tajikistan, Turkmenistan, Uzbekistan, Collective Security Treaty Organization, Shanghai Cooperation Organization, Taliban, Islamic Movement of Uzbekistan, Arab spring.

\section{Introduction}

Russian Federation (RF) throughout the post-Soviet history participated in providing the security in Central Asia. Despite the fact, that after the collapse of the Union of Soviet Socialist Republics (USSR) it started rapid withdrawal from the region, geopolitical factors and new security threats as terrorism, extremism, drug trafficking, illegal migration, ecological problems did not allow it to leave the region ultimately. This article, however, deals with military and political aspects of security.

The presence of Russia in the Central Asian region (CAR) in 1990s was palpable only in Tajikistan, where there was a civil war, which threatened the whole system of regional security. In the other republics Russia had minimum presence which was also connected with the security problems. So in the first half of the 1990s Russia provided the protection of the external borders of the Commonwealth of Independent States in Kirgizia and Turkmenistan (Beloglazov, 2011).

Even American authors, who were criticizing Russia, recognized that at the beginning of the period under consideration, despite its weakening, it had a great impact in the region. J.Kurth stated that Russia went away from the centre of world events to the European periphery and remained as central nation only for Central Asia (Kurth, 2000). But Saul Cohen pointed out, that Russia is located better than the West to provide military stability in Central Asia (Cohen, 2003, p. 226).

At the turn of the XXI century new government of RF began to pay more attention to the security problems in Central Asia. This is not only preserved so far, but also being constantly increased. This is proven by some documents, such as, the Conception of Russian National Security on January 10, 2000, the National security strategy of the Russian Federation up to 2020 on May 12, 2009, as well as three editions of the Concept of the Foreign Policy of the Russian Federation on June 28, 2000, July 15, 2008, and February 12, 2013. CAR is mentioned in these documents as one of the most important regions of political influence of Russia (the Conception of Russian National Security, 2000), "practical measures to strengthen mutual trust and partnership in Central Asian Region" are pointed out (the National security strategy of Russian Federation, 2009), "prevention of destabilization in Central Asia" as a major issue is also stated (Concept of the Foreign Policy of the Russian Federation, 2013).

\section{Methods}

The main method of the study is based on principle of historicism. This means the consideration of Russia's policy on 
providing security in Central Asia in dynamics, the study of its development in certain chronological sequence, its analysis in the context of certain historical conditions. This method was chosen because Russia's policy was not consistent during the last 16 years, it was changing and transforming according to the challenges of situation and opportunities of the country.

The period under consideration has to be divided into logical and chronological sections to point out the dynamics of realization of above mentioned activities and approaches, as well as solution techniques connected with the security issues in Central Asia, also to determine the tools used by Russian Federation to provide that security. As we think there might be four stages in the development of the Russian security policy in Central Asia during the period under consideration: years between 2000-2004, 2004-2008, 2008-2012, and 2012 up to now. Each stage will be analyzed amid world and regional events, with the clarification of the main purposes and achievements of Russia in providing security.

Two interrelated processes make this topic relevant nowadays. These are withdrawal of coalition troops from Afghanistan and the possibility of the development of destructive processes like "Arab spring". It is necessary to point out their impact on Central Asia.

The decision to withdraw International Security Assistance Forces from Afghanistan before 2015 was taken in the NATO Summit in May 2012 (The Chicago Summit Address, 2012). This raised concerns about the increase of such threats as religious extremism, cross-border criminality, and penetration of forces of terrorism from Afghanistan and Pakistan (Tzyan'zhun, 2013). The main contingent of coalition withdrawal had finished by the fall of 2014 (International Security Assistance Force, 3 September 2014). However, the US left 9 military bases in the country, which do not participate in the fight against Islamic organizations, but might become leverage on the Post Soviet Republics of Central Asia, China, India, and Iran.

The terroristic activity of "Taliban" movement intensified amid this. The militants of various extremist organizations, principally Islamic movement of Uzbekistan concentrated on the North of Afghanistan near the borders of Tajikistan, Uzbekistan and Turkmenistan. In October 2014 this movement as well as "Taliban" announced their consolidation with IS. Due to this there increased the threat of not only invasion of Central Asia Republics, but also the replication of "Arab Spring" on their territory.

In each country of Central Asia there are political, social and economical reasons for disaffection and protests. At the same time these might be used by outside forces, interference of which would lead to total destabilization and toppling the regime. The attempts of outside forces to the rebalancing of forces in the region might be caused by the geopolitical position of Central Asia, the presence of enormous hydrocarbon reserves, and also the attempts to create "the second front" for Russia during the Ukrainian crisis.

So, envisaging clearly today's challenges and threats, which formed and accumulated during the period under consideration, Russia's policy would be reviewed step by step.

\section{Results}

\subsection{First stage}

The first stage of Russia's policy on providing security in CAR in the period under consideration started in 2000 and lasted until 2004. Main purpose of the Russian strategy on providing security in Central Asia was the containment of radical Islamism inside the country as well as in the South borders. It was relevant under the terms of intensification of radical Islamic organizations at the turn of centuries and amid second Chechen campaign. To preserve stability in the region Russian government supported any secular regimes, even if they were not friendly.

Initially, Uzbekistan was the main partner in co-operation on security issues. First, Uzbekistan was number one target for the insurgents of Islamic Movement of Uzbekistan. Second, Uzbekistan borders Afghanistan in the South, which was the venue for extremists support and the place where Taliban battled through to the borders of CIS. Third, Uzbekistan is located in the centre of the region and this makes it the most convenient place to coordinate efforts on security issues. For that reason V.V.Putin made his first visit to Tashkent after the inauguration.

Countries of the region made the most important step towards Russia during the next invasion of militants of Islamic Movement of Uzbekistan into Kirgizia and Uzbekistan in August 2000. They knew that without military and political support of Russia they would not be able to resist the push of Islamists, who were supported by Taliban and also by oil monarchy of Persian Gulf. On August 20, 2000 during the meeting in Bishkek, Presidents N.Nazarbayev, A.Akayev, E.Rakhmonov and I.Karimov appealed to Russia to join "Tashkent treaty on joint actions to combat terrorism, political and religious extremism, transnational organized crime or any other threats to stability and security" on April 21, 2000 (Zayavlenie Glav gosudarstv, 2000). 
Right after Russia announced about military and technical support to Kirgizia. At the same time Russia enhanced bilateral cooperation with the countries of Central Asia on security issues. But since 2001 when the threat of Islamic Movement of Uzbekistan declined and Afghan campaign was launched, Uzbekistan began prioritized cooperation with the US. Uzbekistan was the first among Central Asian countries to home American military base in Karshi near Khanabad (Olkott, 2005). Russian government then agreed to US coming to the region, considering that they would curb the penetration of Islamism and extremism from Afghanistan, which would strengthen regional security.

As a result at the first stage of security provision issue main partners of Russia became Kazakhstan, Kirgizia and Tajikistan, which were at the level of establishing united defensive territory. By 2004 they all agreed their air defense system to be modernized by Russia, and also confirmed and entitled Russia for long-term usage of strategic military object on their territories. Most important among them are "Baikonur" cosmodrome and antimissile missile range "SaryShagan" in Kazakhstan, optical electronic complex of space control "Okno" and $4^{\text {th }}$, now $201^{\text {st }}$ base in Tajikistan, Air Force base in Kante, which was opened in 2003, and test bed for naval armaments in Issyk Kul Lake in Kirgizia.

Along with the enhancement of bilateral contacts at this stage of its policy Russia began to build new structure of regional security with the help of integration associations. First of all, Russia became closer to China in the issue of security in the region. So, on June 15, 2001, on the bases of Shanghai Five, there was established Shanghai Cooperation Organization. The tasks of the organization were to prevent and suppress terror attacks, separatism and extremism in Central Asia. After military and political consolidation of the US in the region, and after the start of war in Iraq in 2003, the activity of Shanghai Cooperation Organization was obvious (Jackson, 2007, p.361).

Russia had a great role in establishing the Regional Antiterrorist Structure of Shanghai Cooperation Organization; the Agreement about this organization was signed in the summit on June 7, 2002 in St.Petersburg. Also countries of Shanghai Cooperation Organization by the end of the first stage began to hold joint antiterrorist drills. And the first of it was held in 2003 in Kazakhstan and China.

Along with Shanghai Cooperation Organization, another important tool to provide security in CAR at first stage became Collective Security Treaty Organization, which was established by the initiative of Russia in the summit in Moscow on October 7, 2002. Soon to strengthen its position Russia initiated reform of Collective Rapid Deployment Forces of the Central Asia region. Since 2003 Russian air base in Kirgiz city Kant became an important part of the drills. The same year Russia initiated the signing of multilateral Agreement "On cooperation in protection of external borders of EurAsEC member states" under the frame of Euro Asian economical community, because all member states of the organization were at the same time member of Collective Security Treaty Organization.

\subsection{Second stage}

The period between 2004 and 2008 is characterized by the fact, that Russia participated in the region under the conditions of exacerbated geopolitical confrontation with US, and that notion by the researchers was called "New Big game" (Horkirk, 2006). At this stage it became obvious that US policy in Afghanistan turned up ineffective to suppress Islamist expansion. Americans could not, maybe, they did not want to eliminate the terrorist threat in the region, eradicate "Taliban" movement and curb the production and transporting of Afghan drugs. Each year after the end of military operation and deployment of coalition forces in Afghanistan, production of drugs had a rapid increase (Illicit Drug Trends in Central Asia, April 2008).

At the same time there were pointed out sharp differences in the approach to the security in Central Asia between Russia and US. Three main factors of the impact of the US in the region were inacceptable for Moscow. These are: unrestricted prolongation of American military presence there, an attempt to create system of pipelines bypassing the territory of Russian Federation, and forcing democratic transition of the countries of Central Asia. It was notable during "Tulip revolution" in Kirgizia in March and April 2005, the result of which was the toppling of president A.Akayev. And obviously it was noted in Andijon events in Uzbekistan in May 2005. Also in 2005 right after the election on December 4, on which N.Nazarbayev received more than $91 \%$ of votes, there were planned protests in Kazakhstan.

At this stage maintaining of already created mechanism of regional security was top priority for Russia. Thus, Regional Anti-Terrorist Structure (RATS SCO), which had often been criticized for inaction, intensified its activity. Only in the period between two SCO summits from July, $5^{\text {th }} 2005$ to June, $15^{\text {th }} 2006$ the result of its activity on the SCO territory, mainly on the territory of Central Asia, was prevention of more than 450 acts of terror, arrest or killing of 15 terrorist leaders by Special Services of SCO countries. It was at this stage that Russia and China started conducting annual joint military exercises, the first of which "Peace Mission 2005" was conducted in August. Later it was followed with "Vostok antiterror 2006" and "Peace Mission 2007".

At the same time the Russian Federation intensified cooperation in ensuring security under CSTO (Collective 
Security Treaty Organisation) in a systematic way. In 2004 the organization received an observer status at the United Nations General Assembly. It was since this year that annual joint military exercises conducted to address threats to regional security became systematic. The majority of those exercises took place in Central Asia: "Rubezh 2004" exercises were conducted in the Kyrgyz Republic, "Rubezh 2005" - in Tadzhikistan, "Rubezh 2006" - in Kazakhstan, and "Rubezh 2007" - in the Russian Federation and Tadzhikistan (Ucheniya Rubezh, 2014).

Uzbekistan, whose policy started getting close to Russia after Andizhan massacre, joined the CSTO in 2006, which became an important step for the development of the organization. Before that, American troops had been withdrawn from Karshi-Khanabad Air Base, and in September 2005 Russian-Uzbek joint counter-terrorism exercises were conducted at the Farish military testing ground, $50 \mathrm{~km}$ south of Tashkent.

Concurrently, Russia assisted in strengthening the defense capability of the countries of the region, specifically the weakest links in the CSTO system- the Kyrgyz Republic and Tadzhikistan. As an example, in the period between 20062008, the Kyrgyz Republic was provided with military-technical aid on a gratuitous basis, as well as a part of military equipment and ammunition of the $4^{\text {th }}$ Russian Military Base was handed over to Tadzhikistan, which contributed to considerable strengthening of their fighting potential.

\subsection{Third Stage}

The third stage, which lasted from 2008 to 2012, started under unprecedented pressure on Russia after the peace enforcement operation against Georgia, and at the time of the deepening world economic crisis. All these factors, along with the change of the Russian President, provided limitations for ensuring security in the region.

The crisis made a serious impact on the economies of the countries of Central Asia, resulting in radicalization and dissemination of Islamite sentiment in the region. Consequently, new Islamite groups appeared, propaganda was intensified, and acts of terror became more frequent (Beloglazov, 2013). Taliban's gaining a foothold in Afghanistan and Pakistan contributed to it as well. No wonder that, on February, $4^{\text {th }} 2009$ in Moscow, the leaders of CSTO countries approved of establishing the Collective Rapid Reaction Force (CRRF), intended to be used to repel military aggression, conduct special operations against international terrorism and extremism, against transnational organized crime, drug trafficking, and to conduct emergency relief operations (Mezhdunarodnye otnosheniya v Central'noy Azii, 2011, c. 498). At the same time, joint autumn military exercises of the CSTO countries were conducted in Central Asia: "Rubezh 2009" and "Rubezh 2010" exercise took place in Tadzhikistan.

The weakest country of Central Asia regarding security, Kirghizia, in 2010 passed through another political crisis, which lead to fighting in Bishkek, unseating of the president K. Bakiev, and ethnic clashes in the southern provinces of the Republic (Vasilivetskiy, 2014). The Committee of the Secretaries of the Security Councils (CSSC) was specially convened in June 2010 to tackle the issue of Aid to Kirghizia. CSTO lead the search for organizers of the unrest, and coordinated collaboration in prevention the activity of terrorist groups, which kept the situation under control from Afghanistan; as well as it lead combat against drug mafia, controlling the south of Kirghizia. Besides, in December 2010, having analyzed the recent events in Kirghizia, decisions regarding the establishment of the tool to counteract the crisis situations, and to collectively provide stability, territorial integrity and sovereignty of member countries were agreed upon and approved of at the session of Collective Security Council (CSC) CSTO (Vneshnyaya politika Rossii. Teoriya I praktika, 2013, c.217).

Simultaneously, Russia made great efforts to coordinate the activities of the SCO countries. As an example, in September 2010, large-scale counter-terrorism exercises "Peace Mission 2010" were conducted at "Matybulak" military testing ground in Zhambyl province of Kazakhstan. More than 3000 people from the Russian Federation, China, Kazakhstan, Kirghizia, and Tadzhikistan were involved.

Since the beginning of 2011, the situation with threats to security became more serious with the possibility of destructive processes with external participation on the model of "Arab spring" developing in the region. In this regard, in August 2011 an informal meeting of CSTO presidents took place in Astana with the discussion of the situation in Central Asia regarding "Arab spring", and in December 2011, at the CSC CSTO session in Moscow it was agreed that the powers of the organization would be expanded in matters of activities in case of destabilization of the situation in one of the member countries. Soon after CSTO "Center 2011" military exercises were conducted in four countries simultaneously Russia, Kazakhstan, Kirghizia, and Tadzhikistan, which had never happened before.

\subsection{Fourth stage}

The fourth stage started in 2012 with President V.V. Putin taking office and continues to this day. The top priority of this 
stage is ensuring security in Central Asia in the framework of coalition forces withdrawal from Afghanistan scheduled for 2014. In this respect, Russia pays significant attention to improving and consolidating CSTO. Thus, peacekeeping military exercises of the CSTO member countries' collective forces "Nerushimoe bratstvo 2012" ("Unshakable brotherhood") were conducted at three military testing grounds simultaneously: "lliyskii", "Shoshkala", and "Bereg" in Alma-ata province of Kazakhstan. They contributed to improved coordination of CSTO member countries' armed forces in Central Asia. In September 2013, joint international CSTO battle exercises "Grom 2013" ("Thunder") were conducted in Kirghizia with special units participating.

Besides, CSTO summit was held on September, 23rd 2013. Addressing threats and challenges coming from Afghanistan, and assisting in fortification of Kirghizia and Afghanistan border were focal points of the summit (Vladimir Putin took part in a summit, 2013). Despite the fact that, the next CSTO summit in May 2014 was mainly devoted to discussion of the crisis in Ukraine, ensuring security in Central Asia regarding situation in Afghanistan was on the agenda as well.

At the same time, Russia continued to strengthen its own military installations in the region. An agreement with Almazbek Atambaev was concluded during the visit of V.V.Putin to Kirghizia on September, 19-20 th 2012. According to it, a new merged military base of the Russian Federation on the territory of Kyrgyz Republic is to protect Russian national interests in the region, as well as to defend sovereignty and security of Kirghizia. Besides, it was agreed upon converting the American military transit center at Manas into a transit center for civil purposes.

During the visit to Tadzhikistan, on October, $4-5^{\text {th }}$ 2012, V.V. Putin and E. Rakhmon signed an agreement between the Russian Federation and the Republic of Tadzhikistan on the status and terms of Russian military base on the territory of Tadzhikistan, which prolongs the use of the base up to 2042. Interestingly, the agreement was ratified only in 2014. Presidents V. Putin and E. Rakhmon exchanged the instruments of ratification on February $6^{\text {th }} 2014$ before the Opening ceremony of Olympic Games in Sochi (Latukhina, 2014).

Russia was continuing efforts to consolidate the SCO. Establishing SCO tools for critical incident response, creating the unified register of terrorist groups and people, suspected of being engaged in terrorist activities, expanding cooperation in migration issues were focal questions. At the SCO summits in September 2013 in Bishkek and September 2014 in Dushanbe it was agreed that India and Pakistan upgraded their observer member status to become full members of the organization, which would certainly strengthen it. Some other documents were signed at the summits; they contribute to maintaining peace and stability in Central Asia, specifically 'The program of SCO member countries' cooperation in combating terrorism, separatism, and extremism for 2013-2014", and "Dushanbe Declaration".

In the periods between the summits the organization was constantly working to avert threats to security in Central Asia, which come from Afghanistan and became even more serious in 2014. Thus, consultations were held between the Ministries of Foreign Affairs of SCO member states and observer members on January $22^{\text {nd }} 2014$ in Moscow. The participants expressed their willingness to continue "international assistance to Afghan national security forces by creating more opportunities and increasing financial support with the aim of averting deterioration of the situation in terms of security when the Mission of International Forces is over" (Ob itogah mezhmidovskih konsul'taciy v ramkah SHOS, 2014).

Even more specific was the discussion of regional security issues at the meeting of the Secretaries of SCO Security Councils, which was held on April $17^{\text {th }}$ in Dushanbe. It's interesting that, the Minister of Public Security of the People's Republic of China Guo Shengkun spoke out openly at the meeting. He stated that, the outside forces, which initiate "Colour revolutions" threaten the SCO member states and urged to "identify and analyze them in due time to prevent "Colour revolutions " in order to maintain peace and stability in the region" (Shengkun, 2014)

Ensuring security in Central Asia was also discussed during the visit of V.V.Putin to China in May 2014. It's interesting that, one of the most extensive paragraphs "Statements of the Russian Federation and People's Republic of China on a new level of relationships in comprehensive partnership and strategic cooperation" was devoted to the situation in Afghanistan (Sovmestnoe zayavlenie Rossiiskoy Federacii I Kitaiskoy Narodnoy Respubliki, 2014).

The activities of Russia and China were not limited to appeals and statements only. The fifth joined military exercises "Peace Mission 2014" were a rehearsal of SCO joint activities in averting threats to security in Central Asia. More than 7000 soldiers and nearly 500 units of military equipment were involved. Russia made use of over 1000 soldiers, 60 units of armoured vehicles, 8 helicopters, 4 Su-25 strike-fighters, and 2 IL-76 military-transport aircrafts (Voennosluzhaschie stran SHOS unichtozhili uslovhnyh terroristov v Kitae, 2014). China made use of the units of $38^{\text {th }}$ Army of Beijing Military District, specifically 112nd heavy artillery division, which was among the first who got sophisticated weapons, passed into service of the ground troops of People's Liberation Army. The troops from Kazakhstan, Kirghizia and Tadzhikistan also participated in the exercises. Joint reconnaissance, coordinated strikes against the "maneuver enemy" were trained during the exercises; air-borne and relief operations were staged. It's 
interesting that, a town was built for the exercises at the Czhuzhikhe military testing ground in Inner Mongolia, which was secured by SCO forces, and "the maneuver terrorists" were destroyed. It can be easily seen where such experience might be of great help. According to the Ministry of Defense of the Peoples' Republic of China "in terms of scale and connectedness to real military operations joint counter-terrorism exercises "Peace Mission 2014" are unsurpassed" (Po masshtabam I priblizhennosti, 2014).

Bilateral cooperation in ensuring regional security between Russia and China is of great importance. They cooperatively provide security in Central Asia not only by making use of SCO tools, but by adopting the same policy regarding Syria. This cooperation is a credible deterrent for the "outer forces" in following the "Libyan model", which might lead to dramatically increased threat of escalation of tension in Central Asia.

\section{Discussion}

Russia's policy on providing security of Central Asia in some or other aspects had been reviewed in the works of different researchers, specializing on the region. American authors such as James Kurth (Kurth, 2000), Saul Cohen (Cohen, 2003), Martha Brill Olcott (Olcott, 2005), assessed Russia's policy in the region not very positively, but they admitted that its geopolitical position allows it to provide security and stability in Central Asia more effectively, than Western countries. Canadian researcher Nicole Jackson (Jackson, 2007) considers that any country interested in providing security in Central Asia should cooperate within the framework of Shanghai Cooperation Organization and Collective Security Treaty Organization, though she criticises them for low activity.

European authors evaluate Russia's policy on providing security in Central Asia better. So, British researcher Roy Allison states, that Russia's policy in Central Asia and Caspian region became more efficient since summer 2002 and is corrected in the regard to the new strategic presence of the US here (Allison, 2004). Also German publishers of the respectable encyclopaedic dictionary "Central Asia" recognize the great role of Russia in maintaining peace and security in the region (Zentralasien, 2004).

However, a great number of works, dealing with this topic, was published in Russia. Russian researchers such as Vitaly Naumkin (Naumkin, 2005) and Dina Malysheva (Malysheva, 2013) made a research into certain threats to the security of Central Asia, in particular, religious extremism and drug trafficking, which Russia counteract together with the countries of the region. A number of Russia's steps, directed to maintain peace and stability in the region, is mentioned by the authors in the collective work "International Relations in Central Asia" under the editorship of Alexei Bogaturov (International Relations in Central Asia, 2011).

The monograph of Konstantin Mescheryakov shows a great job of Russia on bilateral cooperation with the countries of Central Asia as well as in the sphere of security (Mescheryakov, 2012). Military and political cooperation of Russia with the countries of Central Asia is mentioned in the work of Alisher Babadzhanov (Babadzhanov, 2014). However, not all Russian authors assess Russia's policy in the region as effective. So, Vagif Guseynov and Nikolai Savkin state, that Russia while providing its policy in Central Asia have no perspective strategy, considering all modern realia (Guseynov, Savkin, 2010).

Besides, certain aspects of the topic are reviewed by the authors from the republics of the region, primarily from Kazakhstan. Kazakh authors Kasym-Zhomart Tokaev (Tokaev, 2008) and Gennadi Chufrin (Chufrin, 2010) highly appreciate the effort of Russian diplomacy in maintaining security in the region. At the same time another Kazakh author Asylbek Bisenbaev (Bisenbaev, 2011) criticizes Russia's policy, considering it not well thought and predictable.

However, none of the above mentioned works analyze the Russia's policy on providing security in Central Asia in complex, they do not cover the period over the last 15 years, its division into periods and main characteristics are not mentioned in these works. Namely these issues are revealed in the current article, which determines its academic novelty.

\section{Conclusion}

Drawing a conclusion, it can be stated that a clear policy of the Russian Federation is observed with regard to the development of bilateral contacts with the countries of Central Asia in ensuring security, and multilateral forms of cooperation within the CSTO and SCO, and within the Collective Rapid Reaction Forces (CRRF) and the Regional AntiTerrorist Structure (RATS SCO).

At the first stage of the period under examination, between 2000-2004, Russia was persistently searching for partners, opening and fortifying military bases and other military installations, establishing the basis for regional security architecture, with new international organizations - SCO and CSTO as its essential elements. 
The second stage, between 2004-2008, was characterized by strengthening of already obtained results, improvements of regional security architecture and training of collaboration with the regional subjects in the context of continuing confrontation with the USA and stronger partnership with China.

The third stage, between 2008-2012, was characterized by aggravation of the situation in the region and in the world, which restricted Russian policy. Nevertheless, Russia succeeded in maintaining its positions in ensuring regional security and conducting larger scale joint exercises.

At the fourth stage of the period, continuing to this day, escalation of inner political situation in Afghanistan is observed, which is caused by withdrawal of coalition forces at the end of 2014, and could result in destructive impact on the whole Central Asia. In these conditions Russia strives for stronger partnership with China as well as for improvements of military infrastructure in the region, and expansion of collaboration within the framework of CSTO and SCO.

Currently, Russia has to take the lead in organizing and coordinating the processes, intended to improve and maintain the regional security system. We reckon it is a precondition to maintaining peace and stability in the region, to prevention the destructive processes on the model of the "Arab spring" in Central Asia, and to stabilization in the region after coalition forces withdrawal from Afghanistan.

Today's top priority for CSTO is fortification of Kirghizia and Afghanistan border and CSTO member countries' joint military exercises, intended to improve coordination in ensuring security in the region. The SCO expands with India and Pakistan upgrading their observer status to become full members of the organization, improves actions against terrorism and extremism and develops concrete measures for stabilization of the situation in Afghanistan, which is currently an observer state in the organization.

Thus, destabilization can be prevented, security and sustainable development ensured when Russia, China and other CSTO and SCO member states work together.

Further examination of the subject must include comprehensive consideration of the situation in Central Asia after coalition forces withdrawal, escalation of social-political tensions in each of the republics of the region, and actions of the Russian Federation to ensure security and stability at the next, fifth stage of its policy in Central Asia in the 21 century.

\section{Recommendations}

Materials of the given article might interest scientists, specializing in the sphere of International Relations and Regional Studies, who conduct research into political processes in Central Asia. They also might be useful for students and postgraduates training in the corresponding speciality. And the article might help while planning concrete political steps on providing security in Central Asia.

\section{References}

Allison R. (2004) Strategic reassertion in Russia's Central Asia policy. International Affairs. L. Vol.80, 2 (277-293)

Babadzhanov A.Y. (2014) Voenno-politicheskoe sotrudnichestvo postsovetskih gosudarstv. M. Aspekt press: 256.

Beloglazov A. V. (2013). Vliyanie islama na politicheskie processy v Central'noy Azii. Kazan. Kazanskiy universitet: 296.

Beloglazov A.V. (2011). Formirovanie politiki Rossii v Central'noy Azii. Kazan. Kazanskiy universitet. 358

Bisenbaev A.K. (2011). Ne vmeste. Rossia i strany Central'noy Asii. Sankt-Peterburg. Piter: 208.

Chufrin G.I. (2010). Rossiya v Central'noy Azii. Almaty. KISI: 220.

Cohen S. B. (2003) Geopolitics of the World System. Lanham. Maryland, Rowman and Littlefield Publishing Group: 436.

Concept of the Foreign Policy of the Russian Federation. Approved by President of the Russian Federation V. Putin on 12 February 2013. Retrieved October 7, 2014, from http://mid.ru/bdomp/ns-osndoc.nsf/1e5f0de28fe77fdcc32575d900298676/869c9d2b87 ad8014c32575d9002b1c38!OpenDocument

Guseynov V, Savkin N. (2010) Rossia i gosudarstva CAR. Centralnaya Asia. In Geopolitica I economika regiona (136-172). M. Krasnaya Zvezda.

Hopkirk P. (2006) The Great Game on Secret Service in High Asia. L. John Murray:.592.

Illicit Drug Trends in Central Asia (2008). UNITED NATIONS. Office on Drugs and Crime Regional Office for Central Asia. April $2008: 52$.

International Security Assistance Force (2014). Troop Contributing Nations. Retrieved March 9, 2015, from http://www.isaf.nato.int/ images/media/PDFs/140904placemat.pdf

Jackson N.J. (2007). Sicherheitskooperation in Zentralasien. Der Kampf gegen Drogenhandel und Terrorismus. In Mactmosaik Zentralasien. Traditionen, Restriktionen, Aspirationen (pp..357-367). Bonn: Lizenzaufgabe für politische Bildung.

Kontseptciya natsional'noi bezopasnosti Rossiyskoy Federatsii (2002). In Vneshnyaya politika I bezopasnost' sovremennoy Rossii. 1991-2002 V. IV. Dokumenty. (pp. 75-89) M.: ROSSPEN.

Kurth J.(2000). The American Way of Victory. A Twentieth - Century Trilogy. The National Interest. Summer 2000. Retrieved October 7 , 2014, from http://nationalinterest.org/article/the-american-way-of-victory-359?page=7 
Latukhina K.(2014) Bazoviy elememt. Rossiya I Tadzhikistan nachali noviy etap sotrudnichestva. Rossiyskaya gazeta (Stolichniy vypusk), \#6299 7. 02.

Malysheva D.B.(2013). Vyzovy bezopasnosti v Central'noy Azii. In Vyzovy bezopasnosti v Central'noy Azii (pp. 5-18). M.: IMEMO RAN.

Mezhdunarodnye otnosheniya v Central'noy Azii.(2011) M. Aspect-press: 549.

Naumkin V.V. (2005). Radical Islam in Central Asia: Between Pen and Rifle. Boulder. Rowman and Littlefield: 285.

Ob itogah mezhmidovskih konsul'taciy v ramkah SHOS po voprosam obespecheniya regional'noy bezopasnosti. Oficial'niy sait SHOS. Retrieved October 7, 2014, from http://sectsco.org/RU123/show.asp?id=76712.

Olkott M.B.(2005). Central Asia's Second Chance. Washington: D.C.: 505.

Po masshtabam i priblishennosti k real'nym boevym deystviyam ucheniya "Mirnaya missiya 2014" prevzoshli vse prezhnie podobnye manyovry (2014). Agentstvo Sin'khua. Retrieved October 7, 2014, from http://russian.news.cn/china/2014-08/28/c_13360 3495. htm

Shengkun G. (2014) Stranam SHOS grozyat "tsvetnye revolutsii". Retrieved October 7, 2014, from http://asiaplus.tj/ru/news/go-shenkunstranam-shos-grozyat-tsvetnye-revolyutsii.

Sovmestnoe zayavlenie Rossiyskoy Federacii I Kitaiskoy Narodnoy Respubliki o novom etape otnosheniy vseob'emlyuschego partnerstva I strategicheskogo vzaimodeistviya (2014). Retrieved October 7, 2014, from http://news.kremlin.ru/ref_notes/1642.

Strategiya nacional'noy bezopasnosti Rossiyskoy Federacii do 2020 goda (2009). Sovet Bezopasnosti Rossiyskoy federacii. Retrieved October 7, 2014, from http:// scrf.gov.ru/documents/99.html

The Chicago Summit Address by NATO Deputy Secretary General Alexander Vershbow to the NATO Parliamentary Assembly Spring Session. Retrieved October 7, 2014, from http://nato.int/cps/ru/natolive/opinions_88137.htm?selectedLocale=ru

Tokaev K-Zh. (2008). Svet I ten'. M. Vostok-Zapad: 544.

Tzyan'zhun Ch. (2013). Vyzovy bezopasnosti v Central'noy Azii posle afganskoy voyny. In Vyzovy bezopasnosti v Central'noy Azii (pp. 86-89). M.: IMEMO RAN.

Ucheniya Rubezh (2014). ODKB. Retrieved October 7, 2014, from http://dkb.gov.ru/ub/a.htm

Vasilibetskiy A. (2014). Prelomlenie. Sobytiya 2010 goda v Kyrgyzstane glazami istorika I ochevidtsev. Bishkek. B.I: 288

Vladimir Putin took part in a summit of the Collective Security Treaty Organization (CSTO) (2014). Russian President's site. Retrieved October 7, 2014, from http://eng.kremlin.ru/news/6021

Vneshnyaya politika Rossii. Teoriya I praktika (2013). M. Kniga I biznes: 543

Voennosluzhaschie stran SHOS unichtozhili uslovnyh terroristov v Kitae. RIA Novosti. Retrieved October 7, 2014, from http://ria.ru/defense_safety/20140829/1021874264.html\#ixzz3C4emzJeA.

Zayavlenie Glav gosudarstv Respubliki Kazakhstan, Kyrgyzskoy respubliki, Respubliki Tadzhikistan, Respubliki Uzbekistan I spetsial'nogo predstavitelya Prezidenta Rossiyskoy Federatsii (2000). Diplomaticheskiy vestnik, 9, (23).

Zentralasien. Geschichte. Politik. Wirtshaft. (2004). Ein Lexikon. München. Druckerei C.H. Beck: 358. 